\title{
Kebijakan Penyelamatan Situs Wonoboyo
}

\section{Tri Hatmadji}

Keywords: CRM, Management, Hindu-Buddha, gold, artifact, archaeology

\section{How to Cite:}

Hatmadji, T. Kebijakan Penyelamatan Situs Wonoboyo. Berkala Arkeologi, 13(3), 8592. https:// doi.org/10.30883/jba.v13i3.619

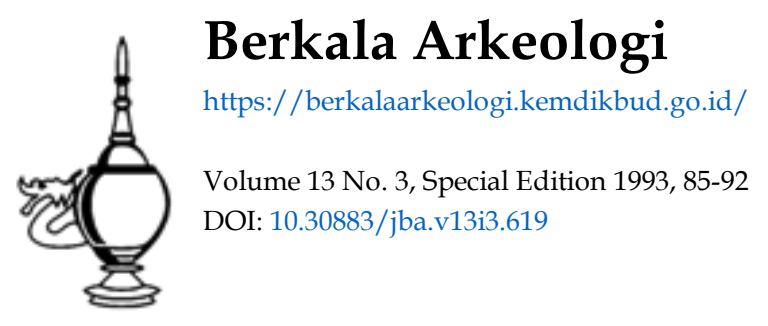

\section{(c) (i) (3)}

This work is licensed under a Creative Commons Attribution-NonCommercial-ShareAlike 4.0 International License. 


\section{KEBIJAKAN PENYELAMATAN SITUS WONOBOYO}

Oron:

Trl Hatmadjl

\section{Pendahuluan}

Pada tanggal 17 OKtober 1990 dl Desa Wonoboyo, Kecamatan Jogonalan, Kabupaten Katen, telah ditemukan dengan tidak sengaja, benda-benda purbakala yang terbuat dari emas, perak dan keramik. Benda-benda purbakala tersebut dlperkirakan berasal darl awal abad IX, hal InI dldasarkan bentuk huruf tullsan singkat (Jawa Kuna) pada mangkuk, dan gambaran yang sama bila dibandingkan dengan relief Ramayana di Candi Prambanan (penggamabaran tokoh-tokoh secara naturalis dan frontal). Disamping guci yang digunakan sebagal wadah benda-benda emas, yang dlklastikasikan sebagal guci dinastl Tang. Temuan tersebut dapat diklasifikasikan menjadl 4 (empat) jenis yaitu, kelompok wadah, perhlasan, mata uang, dan guci.

Melihat data temuan yang sangat menarik Ini, banyak fihak yang ingin mengadakan pancarian benda-benda emas yang diperklrakan masih tertinggal di slitus Wonoboyo. Untuk liu Suaka Peninggalan Sejarah dan Purbakala Jawa Tengah dan Pemda Klaten memandang perlu mengadakan langkah pengamanan. Di samping liu Juga dllkutl dengan mengadakan Penggallan Penyelamatan guna penjajagan terhadap potensi kandungan tinggalan arkeologls di dalam situs, dan untuk memperjelas status tanah lokasl ditemukannya tinggalan tersebut berkenaan dengan eksistensi hukumnya. Ekskavasi Penyelamatan berlangsung tanggal 5 sampal dengan 9 November 1990 dengan melibatkan tenaga Suaka Peninggalan Sejarah dan Purbakala Jwa Tengah, Balal Arkeologl Yogyakarta dan Jurusan Arkeologl Fakultas Sastra Unlversitas Gadjah Mada.

Dalam Ekskavasi telah ditemukan 29 buah pecahan gerabah terdirl darl 22 tragmen badan wadah dan 7 buah fragmen blbir wadah yang dltemukan pada lapisan tanah berwarna coklat, yang diperkirakan tanah permukaan yang asll (sebelum ada timbunan lahar). Kehadiran temuan gerabah ini sebagal petunjuk bahwa dahulu situs tersebut merupakan suatu permuklman. 
Ekskavasi Penyelamatan tahap kedua dllaksanakan karena adanya temuan fragmen bata, batu puth dan sebuah lingga patok darl bahan batu putih serta struktur batu puth, yang membujur arah Barat - Timur. Dengan demikian jelas bahwa tujuan penggallan inl dlmaksudkan umtuk menyelamatkan temuan darl kerusakan dan pemetikan data arkeologisnya. Dalam penggallan yang berlangsung tanggal $10-19$ Desember 1990 berhasil membuka 23 kotak, dengan temuan berupa batu, batu putih dan batu kali balk yang masih berstruktur maupun yang sudah berupa runtuhan. Temuan-temuan balk struktural maupun non struktural yang tersebar di lokasi situs yang cukup luas, merupakan bukti bahwa situs Wonoboyo pernah dipillh sebagal tempat melakukan aktivitas pada masa lampau.

Darl data artefaktual yang diperoleh dalam ekskavasl penyelamatan Wonoboyo ke dua belum dapat untuk menjelaskan jenis atau tipe situs Wonoboyo dan Juge perkiraan luas situs yang harus diselamatkan. Ekskavasl penyelamatan Situs Wonoboyo ketiga dilaksanakan tanggal 19 - 28 Septemiber 1991 dengan melibatkan tim yang lebih besar dengan dipimoin secara Instansional oleh Ditlinbinjarah. Adapun sasaran penggallan inl difokuskan di sekitar area ekskavasI penyelamatan Wonoboyo kedua dan petunjuk alat geollstrik, guna mencari sebaran data arkeologi Wonoboyo. Hasil darl penggallan 23 kotak yang berhasil dlbuka telāh ditemukan data arkeologl terdirl atas: temuan sisa bangunan, temuan artefak (gerabah) dan temuan sisa daun. Temuan sisa bangunan yang terdirl darl bata, batu puth dan batu andesit bulat, balk yang berstruktur maupun yang tidak bertsruktur terdapat pada delapan kotak.

Darl kegiatan penggallan Wonoboyo III dapat disimpulkan bahwa adanya aktivitas manusla, pada masa lalu tidak diragukan lagi. Hanya dapat dlperkirakan bahwa nampaknya situs Wonoboyo merupakan suatu kompleks yang di dalamnya terdirl bangunan-bangunan yang dikellingl oleh pagar tembok. Adapun mengenal denah, bentuk dan sifat bangunannya serta batas-batas willayah situs Wonoboyo masin perlu penellitan lebih lanfut. Sedangkan hasil penelitlan Jurusan Arkeologl Fakultas Sastra UGM, dan Balal Arkeologl Yogyakarta, akan dlbahas secara khusus oleh pemakalah lain pada kesempatan Temu Evaluasl Wonoboyo inl. 


\section{PENYELAMATAN SITUS WONOBOYO KAITANNYA DENGAN PERATURAN PERUNDANGaN.}

Pengertian situs di dalam Undang-undang No. 5 Tahun 1992 tentang Benda Cagar Budaya tertera pada pasal 1, buttr 2 disebutkan bahwa:

."Situs adalah lokasl yang mengandung atau dlduga mengandung benda cagar budaya termasuk lingkungan yang diperlukan bagl pengamanannya".

Selain Itu juga disebutkan di dalam pasal 11:

- Pemerintah menetapkan lokasi penemuan benda cagar budaya atau benda yang diduga cagar budaya sebagaimana dimaksud dalam pasal 10 ayat (1) sebagal situs dengan batas-batasnya".

Suatu hal penting yang perlu diketengahkan lalah bahwa situs adalah sebagal sumberdaya yang terbatas (finite), tak terbarui (non renewable), tak dapat dipindahkan (non moveble) dan rapuh (vulnereble/fragile), sehingga diperlukan penangan situs secara tepat dan benar.

Menyadarl sifat situs seperti terse'but di atas dan usaha menyelamatkan situs Wonoboyo dari ancaman kerusakan oleh penggall liar, maupun aktivitas penggallan untuk menurunkan permukaan tanah guna menunjang usaha pertanian. Ekskavasi penyelamatan mempunyal nilal penting untuk menghindarl kemungkinan kerusakan leblh lanjut dalam suatu situs, mengetahul potensl situs, mengumpulkan data guna rekonstruksi kehldupan masa lampau dan dijadikan dasar sebagal penentu langkah lebih lanjut. Kegiatan ekskavasi penyelamatan di situs Wonoboyo telah beriangsung sebanyak 3 (tiga) kall dan hasllnya secara ringkas telah diuralkan dalam pendahuluan tulisan inl.

Usaha penyelamatan situs Wonoboyo selanjutnya dengan mengkaltkan dirl dalam sewa menyewa tanah untuk dimanfaatkan guna penelltian arkeologis. Instansl kearkeologlan yang mengadakan penyewaan diwakll oleh Suaka Penlnggalan Sejarah dan Purbakala Jawa Tengah, sedangkan tanah yang disewa dari 15 pemllik tanah dengan luas $3.5935 \mathrm{Ha}$. dengan Jangka waktu 2 (dua) tahun terhitung selak 13 September 1991. Adapun sebagal dasar penyewaan lokasi 
situs mengacu hasil ekskavasl penyelamatan dan pertimbangan darl beberapa pakar arkeologis dan untuk areanya telah dlberl patok batas. Untuk dapat memantau area sltus yang disewa dan pengamatan lahan disekitar situs Wonoboyo telah ditempatkan seorang juru pellhara yang bernama Punwanto. Di samping litu Bupati Kepala Daerah Tingkat II Klaten juga telah mengeluarkan Surat Keputusan guna pengemanan dan penanganan situs, yang tertuang dalam Keputusan Bupatl Kepala Daerah Tingkat II Klaten No. 432.3/444/1991, tentang Pembentukan Tim Terpadu Penanganan Situs Wonoboyo, Desa Wonoboyo, Kecamatan Jogonalan, kabupaten Klaten.

Langkah-langkah penyelamatan sltus Wonoboyo kiranya sudah cukup memadal walaupun mungkin masih ada kelemahannya. Melihat usaha penyelamatan sltus Wonoboyo dan mengacu darl hasil keglatan arkeologl yang telah berlangsung sebanyak lima kali dan belum memperoleh data yang lengkap tentang misteri situs Wonoboyo, maka ekskavasl penelltlan Wonoboyo akan mempunyai artl penting untuk mencarl pemecahan tindak lanjutnya. Forum temu wicara yang dlmaksudkan sebagal kebijakan koordinasl penelltian arkeologi Wonoboyo diharapkan mampu menjawab permasalahan dl bawah Inl:

Dimaklumi hasll penggallan penyelamatan / penelltian arkeologi situs Wonoboyo sekarang ini belum dapat menentukan tipe situs, batas-batas situs dan peringkat situs serta pérlu tidaknya situs Wonoboyo dljadlkan wllayah Cagar Budaya. Data yang sangat diperlukan tersebut mellputi:

1. Penllalan tipe situs didasarkan pada krlterla-kriterla dl bidang kepurbakalaan yang bersifat menyeluruh sebagal dasar untuk "pensitusan".

2. Batas-batas situs berkaltan dengan lingkup pemanfaatan dan pelestarlan situs.

3. Perlngkat situs dapat dllakukan dengan cara klaslflkas berdasarkan artefak, struktur, komponen, group monument dan culture rellef status sltus.

4. Penetapan sltus dengan Surat Keputusan Menterl Pendidikan dan Kebudayaan untuk memperoleh kepastlan nukum, sehingga situs dlharapkan tidak terganggu, dan dijamin untuk pengamanannya oleh undang-undang yang berlaku. 
Untuk menjawab permasalah tersebut kiranya perlu dikajl materi Rencana Peraturan Pemerintah Republlk Indonesia tentang Pelaksanaan Undang-undang No. 5 Th. 1992 tentang Benda Cagar Budaya Bab VII Ketentuan lain pasal 22 ayat (3).

Berdasarkan hasil studl arkeologis terhadap rencana keglatan pembangunan tersebut, Menterl dapat menyatakan:

a. tetap mempertahankan keberadaan benda cagar budaya dan situs; atau

b. menghapus benda cagar budaya atau situs dari daftar; atau

c. menyarankan diubahnya rencana pembangunan; atau

d. memindahkan benda cagar budaya dari situs; atau

e. menyetujui dilanjutkannya rencana keglatan tersebut.

Bertitlk tolak darl bunyl peraturan pemerintah di atas kita mendapat tantangan secara tegas tentang status situs Wonoboyo yaltu:

1. Mempertahankan situs Wonoboyo dengan dapat menjawab tipe situs, batas situs, peringkat situs, dan tata cara lainnya guna persyaratan "pensitusan". Disamping litu apabila telah dapat menyatakan sebagal "situs" harus dlikutl dengan batas-batas zoningnya. Hal Ini sesaul dengan Peraturan Pemerintah Bab IV Perlindungan dan Pemeliharaan pasal 23 ayat (3) yang berbunyl: Batas-batas situs dan lingkungannya ditetapkan dengan sistem pemintakatan ( zoning ) yang terdirl darl zona (mintakat) intl, zona penyangga dan zona pengembangan.

2. Menghapus Benda cagar budaya dan situs Wonoboyo darl daftar dengan memindahkan benda cagar budaya darl situs Wonoboyo. Alternatlf Inl nantinya akan dllaksanakan apablla Tim Penellti situs Wonoboyo tldak berhasil menyajkan syarat-syarat "pensitusan" dan Jatuh gillrannya mungkin cukup dengan didokumentasikan saja (preserved by record).

Penellan dan perlakuan situs Wonoboyo sangat ditentukan nasibnya oleh hasil penellitan-penellitian yang akan datang. Data arkeologl yang telah diperoleh darl hasll ekskavasl penyelamatan I penellitan arkeologi klranya maslh menunjukkan prospek yang terang 
untuk ditindaklanjutl.

Hal Inl berkaltan dengan optimlsme Drs. Ph. Subroto MSc. yang menyatakan apabila data yang diperlukan dapat diperoleh dari penelltlan Wonoboyo, maka misteri situs Wonoboyo pastl akan terungkap. Terungkapnya minsteri ini berarti akan membuka kernungkinan-kemingkinan baru dalam bidang Sejarah Kuna, seperti dlketahui bahwa sampal saat ini di Jawa Tengah belum ditemukan situs yang kemungkinan bekas kraton di masa Mataram Kuno. Hal Ini tentunya sangat ironos, mengingat di Jawa Tengah terdapat banyak sekail peninggalan arkeologi yang berupa bangunan-bangunan candl dari periode Mataram Kuno, baik candi yang bersifat Budha maupun Hindu.

Harapan untuk menyingkap misteri situs Wonoboyo banyak diharapkan oleh semua pihak, sslalu timbul pertanyaan apakah situs Wonoboyo dianggap telah mewakdil kebudayaan tertentu, seperti halnya situs Sriwijaya dan sltus Majapahit. Suatu tantangan besar bagi pakar arkeologi untuk menjawabnya. Untuk itu penanganan penelitian situs Wonoboyo yang sedang berjalan untuk mencapai tujuan akhir penelitian (rekonstruksi kehidupan situs Wonoboyo secara utuh) periu mendapatkan śxala prioritas penelitian semua instansi kearkeologian. Oi samping perhatian dan bantuan Instansi pemerintah terkait dan peranserta masyarakat. Klranya kita semua sepakat bahwa tidak ada seorang pun warga negara Indonesia yang menglnginkan hilangnya berbagai benda cagar budaya dan sltusnya demi kepentingan apapun.

\section{BEBERAPA KESIMPULAN DAN SARAN}

Darl uralan-uraian tersebut sebaiknya kita ambll beberapa kesimpulan dan saran.

\section{A. Kesimpulan}

1. Keglatan yang telah dilaksanakan dalam upaya penyelamatan benda cagar budaya dan situs Wonoboyo secara teknls arkeologls tolar dijalankan sesual aturan yang berlaku.

2. Keglatan ekskavasł penyelamatan yang dlmaksudkan untuk menyelamatkan benda cagar budaya dan sltusnya dari ancaman atau bahaya kerusakan yang dlakibatkan keglatan manusia yang 
bersifat mendesak, telah ditanganl secara cepat tanpa meninggalkan metode dan teknik yang berkembang dalam IImu arkeologi.

3. Hasil ekskavasi penyelamatan / penelitian arkeologl yang telah dilakukan belum mendapatkan data yang cukup sebagal syarat "pensitusan" yang dapat menggambarkan nilai kepentingannya.

4. Perlu mengiventarlsas/kan kekurangan data yang diperlukan untuk proses pensitusan, sehingga pengkerangkaan parelitian arkeologl perlu dilakukan secara maksimal.

5. Pelaksanaan kegiatan penelitian, baik yang bersifat teknis I administratli dengan cara koordinas! antar instansi kearkeologian perlu lebih dimantapkan dan peranserta masyarakat dan Pemerintah Daerah Tk. II Kabupaten Klaten akan menunjang keberhasilan penelitlan yang selama ini masih ngambang.

\section{B. Saran-saran}

1. Membentuk badan khusus untuk menampung penyandang dana yang berminat dalam penangan penelitian situs Wonobo:yo.

2. Merumuskan kerangka penellian jangka pendek maupun panjang dengan tim khusus yang terkoordinir.

3. Penyewaan tanah terus dilakukan sebelum dinyatakan status situs Wonoboyo (dlpertahankan / dihapus).

4. Pengggalakan kesadaran masyarakat sekitar akan arti pentingnya benda cagar budaya dan situs yang sedang ditelitl.

5. Dengan terbitnya Undang-undang RI No. 5 Th. 1992 pemerintah harus dapat mengimbangi dari segala konsekuensi yang tImbul darl hasil penelitlan sltus Wonoboyo, utamanya masalah pendanaannya, guna penyelamatan situs Wonoboyo yang berkaitan dengan kepentingan masyarakat. 


\section{KEPUSTAKAAN}

Anonim, 1992, Undang-undang Republik Indonesia No. 5 Tahun 1992.

1992. Rancangan Peraturan Pemerintah Republik Indonesia No. Th. tentang pelaksanaan Undang-undang No. 5 Tahun 1992.

1990, Laporan Ekskavasi Penyelamatan Situs Wonoboyo, tanggal 5 s.d. 9 Nopember 1990.

1990, Laporan Ekskavasi Penyelamatan Situs Wonoboyo, tanggal 10 s.d 19 Desember 1990.

1991. Laporan Ekskavasi Penyelamatan Situs Wonoboyo, tanggal 19 s.d. 28 September 1991.

1991. Pedoman Pongelolaan Peninggalan Sejarah dan Purbakala, diterbitkan oleh Proyek Pelestarian / Pemanfaatan Peninggalan Sejarah dan Purbakala Jakarta 1991.

Drajat. Harl Untoro, 1992, Penyelamatan Arkeologi, Penyusunan Potunjuk Teknis, Borobudur 29 September s.d. 2 Oktober 1992.

Tri Hatmadjl. 1992, Pengamanan Benda Cagar Budaya. Penyusunan Petunjuk Teknis, Borobudur 29 September s.d. 2 Oktober 1992. 